\title{
Peningkatan kepedulian lingkungan melalui pembinaan penerapan sistem $3 R$ (reduce, reuse, recycle)
}

\author{
Henny Helmi $^{1}$ *, Yanti Karmila Nengsih ${ }^{1}$, Vina Amilia Suganda ${ }^{2}$ \\ ${ }^{1}$ Pendidikan Luar Sekolah, Universitas Sriwijaya. Jalan Raya Palembang-Prabumulih Km 32 \\ Indralaya Ogan Ilir, Sumatera Selatan, Indonesia \\ ${ }^{2}$ Pendidikan Guru Sekolah Dasar, Universitas Sriwijaya. Jalan Raya Palembang-Prabumulih Km \\ 32 Indralaya Ogan Ilir, Sumatera Selatan, Indonesia \\ *Corresponding Author. Email: hennyhelmi@unsri.ac.id, Telp: +6285269645644 \\ Received: 19 November 2017; Revised: 12 March 2018; Accepted: 13 March 2018
}

\begin{abstract}
Abstrak
Penelitian ini bertujuan untuk mendeskripsikan upaya meningkatkan kepedulian masyarakat terhadap kebersihan dan kesehatan lingkungan melalui pembinaan penerapan sistem $3 \mathrm{R}$ (Reduce, reuse, recycle) di Kelurahan Kebun Bunga Palembang. Penelitian ini adalah penelitian tindakan dengan subjek penelitian masyarakat RT 30 dan RT 39 Kelurahan Kebun Bunga Palembang sebanyak 10 keluarga. Teknik pengumpulan data dilakukan dengan metode wawancara, observasi, serta dokumentasi. Penelitian berlangsung dalam dua siklus. Hasil pretest pada siklus I, tidak ada satu pun warga yang mengetahui dan memahami konsep pengelolaan sampah dengan menggunakan sistem ${ }_{3} R$. Setelah pelaksanaan tindakan pada siklus I, terdapat peningkatan pengetahuan masyarakat mengenai sistem ${ }_{3} \mathrm{R}$ namun belum sampai pada tahap aplikasi. Pada siklus II, tindakan ditekankan pada pembinaan kader lingkungan. Hasil observasi siklus II didapatkan adanya peningkatan kepedulian terhadap lingkungan yang mencakup pengetahuan, sikap dan penerapan sistem ${ }_{3} \mathrm{R}$ di lingkungan rumah masing-masing.
\end{abstract}

Kata Kunci: kepedulian lingkungan, sistem $3 \mathrm{R}$, pendidik masyarakat, pembinaan.

\section{Improving the environmental care through implementation of $3 R$ system (reduce, reuse, recycle)}

\begin{abstract}
The research aimed to describe the effort to improve the communities' care to clean and health environment through implementation of $3 R$ system (Reduce, reuse, recycle) in Kebun Bunga hamlet, Palembang, South Sumatera. The research was action research, and the subject of the research were communities in RT (Neighbor Association) 30 and RT 39 in Kebun Bunga Hamlet, Palembang, the amount of the subject was io families. Data collection techniques were interview, observation, and documentation. The research conducted in two cycles. The pretest result of cycle I was; there was no person who knows and understands the concept of waste management using $3 R$ system. After the treatment in cycle $I$, there was an improving of communities understanding to $3 R$ system of waste management, but it might not reach to the application. In cycle II, the treatment emphasized on guidance to environmental ambassador. The result of observation in cycle II: there was an improving of environmental care including knowledge, attitude, and implementation of $3 R$ system in the surrounding house of the communities.
\end{abstract}

Keywords: environmental care, $3 R$ system, communities' educator, guidance

How to Cite: Helmi, H., Nengsih, Y., \& Suganda, V. (2018). Peningkatan kepedulian lingkungan melalui pembinaan penerapan sistem ${ }_{3} \mathrm{R}$ (reduce, reuse, recycle). JPPM (Jurnal Pendidikan dan Pemberdayaan Masyarakat), 5(1), 1-8. doi:http://dx.doi.org/10.21831/jppm.v5i1.16861

do

http://dx.doi.org/10.21831/jppm.v5i1.16861

Copyright $@$ 2018, JPPM, ISSN 2355-1615 (print), ISSN 2477-2992 (online) 
JPPM (Jurnal Pendidikan dan Pemberdayaan Masyarakat), 5 (1), 2018 - 2

Henny Helmi, Yanti Karmila Nengsih, Vina Amilia Suganda

\section{PENDAHULUAN}

Lingkungan adalah semua benda dan kondisi termasuk didalamnya manusia dan aktivitasnya, yang terdapat dalam ruang dimana manusia berada dan mempengaruhi kelangsungan hidup serta kesejateraan manusia dan jasad hidup lainnya (Darsono, 1995). Pakar lain menyebutkan bahwa lingkungan adalah suatu sistem kompleks yang berada di luar individu yang mempengaruhi pertumbuhan dan perkembangan organisme. Setiap organisme hidup dalam lingkungannya masing-masing. Antara organisme dan lingkungan terjalin hubungan yang erat dan bersifat timbal balik. Tanpa lingkungan organisme tidak mungkin ada, sebaliknya lingkungan tanpa organisme, tidak berarti apa-apa (Irwan, 2007).

Menurut Undang-Undang RI No 32 Tahun 2009 tentang Perlindungan dan Pengelolaan Lingkungan Hidup, lingkungan hidup adalah kesatuan ruang dengan semua benda, daya, keadaan, dan makhluk hidup, termasuk manusia dan perilakunya, yang mempengaruhi alam itu sendiri, kelangsungan perikehidupan, dan kesejahteraan manusia serta makhluk hidup lain (Presiden Republik Indonesia, 2009). Menurut seorang ahli ilmu lingkungan, Soemarwoto (1997), lingkungan hidup adalah jumlah semua benda dan kondisi yang ada dalam ruang yang kita tempati yang mempengaruhi kehidupan kita. Sedangkan menurut Emil Salim, lingkungan hidup adalah segala benda, kondisi, keadaan dan pengaruh yang terdapat dalam ruangan yang kita tempati dan mempengaruhi hal yang hidup termasuk kehidupan manusia (Neolaka, 2008). Berdasarkan definisi-definisi yang telah dikemukakan beberapa tokoh tersebut, dapat diambil benang merah bahwa lingkungan hidup adalah segala sesuatu yang terdapat dalam ruang yang ditempati dan mempengaruhi keseluruhan hidup manusia dan makhluq hidup lainnya.

Sifat lingkungan hidup ditentukan oleh bermacam-macam faktor. Pertama, jenis dan jumlah masing-masing jenis unsur lingkungan hidup. Kedua, hubungan atau interaksi antara unsur dalam lingkungan hidup itu. Ketiga, kelakuan atau kondisi unsur lingkungan hidup. Keempat, faktor non-materiil seperti suhu, cahaya dan kebisingan. Manusia berinteraksi dengan lingkungan hidupnya. Interaksi antara manusia dengan lingkungan hidupnya sangat kompleks, karena dalam lingkungan hidup terdapat banyak unsur. Pengaruh terhadap suatu unsur akan merambat pada unsur lain, sehingga pengaruhnya terhadap manusia sering tidak dapat dengan segera terlihat dan terasa (Soemarwoto, 1997).

Manusia hidup dari unsur-unsur lingkungan hidupnya: udara untuk pernafasannya, air untuk minum, keperluan rumah tangga, tumbuhan dan hewan untuk makanan, tenaga dan kesenangan, serta lahan untuk tempat tinggal dan produksi pertanian (Soemarwoto, 1997). Oleh karena manusia sangat membutuhkan lingkungan untuk keberlangsungan kehidupannya, maka sudah sepatutnyalah manusia memperhatikan lingkungan dimana tempat ia hidup, tinggal dan menetap. Sangat penting bagi manusia untuk menciptakan lingkungan yang bersih dan sehat mengingat hal ini berdampak pada kehidupan manusia itu sendiri. Lingkungan yang bersih menciptakan kehidupan yang nyaman dan menyehatkan.

Untuk menciptakan lingkungan yang bersih dan sehat, antara faktor lingkungan dan komponen lingkungannya haruslah seimbang. Manusia perlu memiliki etika lingkungan yang benar untuk hidup dengan lingkungannya. Manusia mesti menyadari bahwa ia merupakan bagian dari lingkungannya. Manusia juga harus menyadari bahwa dialah yang membutuhkan lingkungan (Neolaka, 2008). Dengan timbulnya kesadaran akan muncul sikap peduli, dengan peduli terhadap lingkungan maka akan terwujud perilaku menjaga lingkungan dengan baik. Dengan demikian, lingkungan akan menjadi sehat serta dapat memberikan kontribusi yang positif terhadap keberlangsungan hidup manusia.

Peduli terhadap lingkungan berarti ikut melestarikan lingkungan hidup dengan sebaik-baiknya, bisa dengan cara memelihara, mengelola, memulihkan serta menjaga lingkungan hidup.

Kebersihan dan kesehatan lingkungan merupakan keniscayaan bagi siapa saja yang 


\section{JPPM (Jurnal Pendidikan dan Pemberdayaan Masyarakat), 5 (1), 2018 - 3}

Henny Helmi, Yanti Karmila Nengsih, Vina Amilia Suganda

mendambakan hidup sehat dan nyaman. Dengan kata lain, setiap orang yang menginginkan hidup sehat dan nyaman, harus memperhatikan kebersihan dan kesehatan lingkungan dimana dia tinggal dan menetap. Jika lingkungan bersih maka kesehatan lingkungan pun dapat terwujud. Hidup menjadi nyaman karena ancaman dari berbagai macam penyakit dapat diminimalisir. Lingkungan yang bersih dan sehat dapat tercipta jika perilaku masyarakat juga bersih dan sehat.

Perilaku masyarakat yang membuang sampah sembarangan merupakan salah satu penyebab rusaknya lingkungan. Berdasarkan studi pengamatan terbatas, banyak masyarakat di beberapa kota yang membuang sampah sembarangan di jalan-jalan umum bahkan sampai ke jalan protokol. Tidak sedikit masyarakat yang membuang sampah di sisi jalan umum terutama di tempattempat yang tidak berpenghuni. Kegiatan membuang sampah sembarangan ini biasanya dilakukan pada pagi hari ketika belum banyak orang beraktivitas di luar rumah atau pada malam hari ketika orang sudah tidak banyak lagi beraktivitas di luar rumah. Ini memberi kesan bahwa mereka yang membuang sampah di sembarang tempat, tidak ingin kegiatannya ini diketahui oleh orang lain. Hal ini menunjukkan bahwa mereka mengetahui bahwa apa yang telah dilakukannya (membuang sampah tidak pada tempatnya) adalah tindakan yang salah.

Demikian pula halnya yang terjadi di kota Palembang kelurahan Kebun Bunga. Berdasarkan studi pengamatan terbatas, terdapat beberapa titik penumpukan sampah yang bukan merupakan tempat pembuangan sampah sementara. Beberapa masyarakat membuang sampah bukan pada tempat semestinya melainkan di sisi-sisi jalan umum. Bahkan ketika pagi hari terjadi penumpukan sampah di sisi jalan protokol Haji Burlian. Lahan kosong dan sisi jalan umum yang sepi juga tidak luput menjadi tempat pembuangan sampah sembarangan yang dilakukan oleh beberapa warga. Sampah yang banyak berasal dari limbah rumah tangga dibiarkan begitu saja tanpa ada pengelolaan yang baik dan benar.
Berdasarkan data tersebut dapat ditemukan beberapa permasalahan sebagai berikut: (1) Rendahnya pengetahuan masyarakat tentang pengelolaan sampah yang baik dan benar; (2) Rendahnya pemahaman masyarakat terhadap pentingnya menjaga kebersihan dan kesehatan lingkungan; (3) Rendahnya kepedulian masyarakat terhadap kebersihan dan kesehatan lingkungan.

Berdasarkan beberapa permasalahan tersebut maka diperlukan sebuah upaya untuk meningkatkan kepedulian masyarakat terhadap kebersihan dan kesehatan lingkungan agar kesehatan masyarakat dapat tercipta. Upaya meningkatkan kepedulian masyarakat terhadap lingkungan dapat dilakukan melalui pendidikan terhadap masyarakat. Di sini peran pendidik masyarakat sebagai agen perubahan sosial sangat diperlukan. Pendidik masyarakat perlu melakukan pembinaan terhadap masyarakat agar masyarakat tahu, mau dan akhirnya dapat mengaplikasikan tindakan yang baik dan benar.

Salah satu upaya menciptakan lingkungan yang bersih dan sehat yang mudah dan murah adalah dengan menerapkan sistem ${ }_{3} \mathrm{R}$ (Reduce, reuse, recycle). Sistem ${ }_{3} \mathrm{R}$ yaitu Reduce, reuse dan recycle adalah sistem pengelolaan sampah yang berorientasi pada pencegahan timbulnya sampah, meminimalisir sampah dengan memanfaatkan kembali barang yang masih dapat digunakan, mendaur ulang sampah menjadi sesuatu yang bermanfaat serta penerapan pembuangan sampah yang ramah lingkungan. Sistem ${ }_{3} \mathrm{R}$ ini sebenarnya sudah cukup lama diluncurkan oleh pemerintah. Hanya saja tidak setiap masyarakat yang mengetahuinya.

Reduce atau reduksi sampah merupakan upaya untuk mengurangi timbulan sampah di lingkungan sumber dan bahkan dapat dilakukan sejak sebelum sampah dihasilkan. Setiap sumber dapat melakukan upaya reduksi sampah dengan cara merubah pola hidup konsumtif menjadi hemat atau efisien. Kegiatan reduksi sampah misalnya membawa tas atau kantong pada saat berbelanja, lebih memilih menggunakan sapu tangan dibandingkan penggunaan tissue, 
JPPM (Jurnal Pendidikan dan Pemberdayaan Masyarakat), 5 (1), 2018 - 4

Henny Helmi, Yanti Karmila Nengsih, Vina Amilia Suganda

membeli produk yang bisa diisi ulang atau tidak membeli produk sekali pakai.

Reuse adalah menggunakan kembali bahan atau material agar tidak menjadi sampah. Misalnya menggunakan sisi kertas yang masih kosong untuk menulis, menggunakan kembali botol bekas minuman untuk mengisi air, mengisi kaleng susu dengan susu refiil dan lain sebagainya. Sedangkan recycle adalah mendaur ulang suatu bahan yang sudah tidak berguna (sampah) menjadi bahan lain setelah melalui proses pengolahan. Misalnya, memanfaatkan dan mengolah ban bekas menjadi pot bunga, mengolah sisa kain perca menjadi selimut atau keset kaki, mengolah sampah organik menjadi pupuk kompos dan lain sebagainya.

Dengan demikian, pengolahan sampah dengan menggunakan metode $3 \mathrm{R}$ menekankan pada pengurangan sampah dengan lebih arif dan ramah lingkungan. Pendidik masyarakat dapat melakukan edukasi mengenai sistem $3 \mathrm{R}$ ini terhadap masyarakat agar kebersihan dan kesehatan lingkungan dapat tercipta.

Penelitian ini bertujuan untuk mendeskripsikan upaya meningkatkan kepedulian masyarakat terhadap kebersihan dan kesehatan lingkungan melalui pembinaan penerapan sistem 3R (Reduce, reuse, recycle) di Kelurahan Kebun Bunga Palembang.

\section{METODE}

Penelitian ini mengunakan metode kualitatif dengan pendekatan penelitian tindakan. Penelitian tindakan merupakan salah satu pendekatan penelitian ilmiah yang mempunyai dua tujuan yaitu mengambil tindakan (untuk perbaikan) dan membangun pengetahuan atau teori tentang tindakan (Sugiyono, 2015).

Subjek pada penelitian ini adalah masyarakat RT 30 dan RT 39 Kelurahan Kebun Bunga Kecamatan Sukarami sebanyak 1o keluarga. Teknik pengumpulan data dilakukan dengan metode wawancara, observasi serta dokumentasi.

Konsep pokok penelitian tindakan terdiri dari empat langkah dalam bentuk spiral, yaitu: (1) Planning atau perencanaan, (2) tindakan atau acting, (3) pengamatan atau observing, (4) refleksi atau reflecting
(Burns, 1999). Adapun dalam penelitian ini, dijelaskan sebagaimana berikut:

\section{Perencanaan Tindakan}

Perencanaan tindakan meliputi refleksi awal, identifikasi masalah penetapan dan perumusan rancangan tindakan. Peneliti melakukan refleksi awal bersama partisipan dalam program yang akan diteliti. Dalam kegiatan ini peneliti bersama partisipan melaksanakan observasi awal dan mencari informasi lain untuk mengenali dan mengetahui kondisi awal mengenai lingkungan di Kelurahan Kebun Bunga Palembang. Setelah itu peneliti bersama partisipan melakukan identifikasi masalah dan merencanakan tindakan bersama partisipan untuk mengatasi permasalahan yang ada. Selain merencanakan tindakan apa yang akan dilakukan, peneliti bersama partisipan juga merencanakan langkah-langkah tindakan, instrumen untuk mengukur keberhasilan tindakan serta lembar pengamatan untuk mengamati proses tindakan.

\section{Pelaksanaan Tindakan}

Pada tahap ini peneliti dan partisipan melakukan tindakan yang telah direncanakan sebelumnya. Selama tindakan berlangsung peneliti melakukan pengamatan secara sadar, kritis, dan objektif dalam memantau pelaksanaan tindakan. Pengamatan pemantauan ini secara komprehensif diharapkan dapat mengenali dan merekam dengan lengkap gejala-gejala baik yang memang direncanakan mau pun yang tidak direncanakan, yang cenderung mempertinggi mau pun yang menurunkan efektivitas tindakan.

\section{Pemantauan (Observasi)}

Observasi berfungsi mendokumentasikan pengaruh tindakan terkait bersama prosesnya (Madya, 2007). Observasi di sini dimaksudkan sebagai kegiatan untuk mengenali, merekam, dan mendokumentasikan semua gejala indicator dari proses dari hasil yang dicapai, perubahan yang terjadi, baik yang ditimbulkan oleh tindakan terencana mau pun efek sampingan, mau pun bahkan pada efek sampingannya. Pemantauan merupakan bagian dari evaluasi, tetapi lebih ditekankan pada: (1) seberapa jauh pelaksanaan 


\section{JPPM (Jurnal Pendidikan dan Pemberdayaan Masyarakat), 5 (1), 2018 - 5}

Henny Helmi, Yanti Karmila Nengsih, Vina Amilia Suganda

intervensi sesuai dengan rencana yang telah tersusun sebelumnya; (2) seberapa jauh proses yang terjadi dapat diharapkan menuju pasaran yang diharapkan. Dengan pemantauan diharapkan gejala ketidakberhasilan atau kesalahan dalam rancangan tindakan dapat terdeteksi sedini mungkin, sehingga dapat dilakukan modifikasi rancangan tindakan.

\section{Refleksi}

Pada tahap akhir, peneliti bersama partisipan melakukan refleksi terhadap hasil dari tindakan. Refleksi adalah mengingat dan merenungkan kembali suatu tindakan persis seperti yang telah dicatat dalam observasi (Madya, 2007). Refleksi merupakan bagian yang sangat penting untuk memahami dan memberikan makna terhadap proses dan hasil perubahan yang terjadi sebagai akibat adanya intervensi tindakan. Refleksi juga sangat bermanfaat untuk meningkatkan kualitas dan kemampuan tim peneliti dalam penelitian tindakan. Refleksi dilaksanakan melalui Forum Group Discussion sehingga menghasilkan rekonstruksi makna situasi sosial dan memberikan dasar perbaikan rencana.

\section{HASIL DAN PEMBAHASAN}

\section{Pratindakan Penelitian Tindakan Partisapatoris}

Peneliti melakukan kegiatan pratindakan sebelum melaksanakan tindakan bersama masyarakat setempat. Kegiatan pratindakan difokuskan untuk mengetahui permasalahan mengenai pengelolaan lingkungan hidup dan tingkat pengetahuan masyarakat mengenai pengelolaan limbah dengan sistem $3 R$.

Hasil observasi dan wawancara yang peneliti dapatkan adalah sebagai berikut: (1) Banyak masyarakat yang belum mengetahui pengelolaan limbah dengan sistem $3 \mathrm{R}$; (2) Banyak masyarakat yang belum mengetahui pemilahan sampah onganik dan anorganik; (3) Banyak masyarakat mengalami kebingungan membuang sampah dengan alasan tidak tersedianya tempat membuang sampah/limbah; (4) Terdapat masyarakat yang tidak mempedulikan dampak perbuatan membuang sampah sembarangan.

\section{Deskripsi Penelitian Siklus I}

Penelitian siklus 1 dilaksanakan pada tanggal 25 Agustus 2017 sampai dengan 31 Agustus 2017.

\section{Perencanaan Tindakan Siklus I}

Perencanaan Tindakan Siklus I meliputi (1) Membuat rencana pelatihan dan penyuluhan Kepedulian Lingkungan dengan tema: Penyuluhan dan Pelatihan Pengelolaan Sampah dengan Sistem 3R; (2) Menyiapkan materi penyuluhan dan pelatihan; (3) Menyiapkan bahan, alat dan media yang diperlukan; (4) Menyiapkan lembar pengamatan ketercapaian masyarakat dalam menerapkan materi penyuluhan dan pelatihan; (5) Mempersiapkan kuisioner

Pelaksanaan Tindakan Siklus I

Pelaksanaan Tindakan Siklus I meliputi (1) Pre-test; (2) Mengadakan Penyuluhan mengenai pengelolaan lingkungan; (3) Mengadakan pelatihan pengelolaan sampah dengan menggunakan sistem $3 \mathrm{R}$; (4) Post Test.

\section{Hasil Observasi Siklus I}

Sebelum pelaksanaan penyuluhan dan pelatihan penerapan sistem $3 \mathrm{R}$ di lingkungan kelurahan kebun bunga pada tanggal 25 Agustus 2017, peneliti melaksanakan pre test terkait pengetahuan, sikap dan perilaku responden mengenai sistem ${ }_{3} R$. Dari hasil pre test yang didapatkan, tidak ada satu pun warga yang mengetahui dan memahami konsep pengelolaan sampah dengan menggunakan sistem $3 R$. Setelah pelaksanaan penyuluhan dan pelatihan mengenai sistem $3 \mathrm{R}$, peneliti melakukan post-test yang hasilnya menunjukkan adanya peningkatan pengetahuan masyarakat mengenai penerapan sistem ${ }_{3} R$. Setelah beberapa hari pasca penyuluhan dan pelatihan, peneliti mengobservasi sikap warga dalam hal penerapan sistem $3 \mathrm{R}$ di lingkungan rumah masingmasing. Data yang peneliti temukan di lapangan, hanya 4 dari $10 \mathrm{ibu}$ rumah tangga yang sudah menerapkan sistem ${ }_{3} \mathrm{R}$ di lingkungan rumahnya sendiri. 
JPPM (Jurnal Pendidikan dan Pemberdayaan Masyarakat), 5 (1), 2018 - 6

Henny Helmi, Yanti Karmila Nengsih, Vina Amilia Suganda

Refleksi Tindakan Siklus I

Berdasarkan hasil post-test, tingkat pengetahuan masyarakat mengenai sistem $3 \mathrm{R}$ setelah diadakan penyuluhan menunjukkan peningkatan yang cukup baik. Namun pengetahuan yang warga miliki belum sampai pada tahap aplikasi. Hal ini sesuai dengan hasil observasi yang menunjukkan bahwa hanya 4 dari 10 ibu rumah tangga yang menerapkan sistem $3 \mathrm{R}$ di lingkungan rumahnya sendiri. Oleh karena itu, peneliti perlu melakukan rencana tindakan untuk siklus kedua. Berdasarkan hasil diskusi tim peneliti, peneliti perlu menambahkan materi penyuluhan mengenai etika lingkungan yang juga dikaitkan dengan nilai-nilai agama. Selain itu, peneliti juga merencanakan pembentukan dan pembinaan kader lingkungan yang terdiri dari ibu-ibu warga setempat yang mempunyai pengaruh cukup kuat terhadap ibu-ibu lainnya.

\section{Deskripsi Penelitian Siklus II}

Penelitian siklus II dilaksanakan pada tanggal 8 September 2017 sampai 22 September 2017.

\section{Perencanaan Tindakan Siklus II}

Perencanaan Tindakan Siklus II meliputi (1) Menyiapkan materi penyuluhan tahap 2 dengan penambahan mengenai etika lingkungan dan dikaitan dengan nilai-nilai agama; (2) Merencanakan pembentukan kader sadar lingkungan yang terdiri dari ibuibu rumah tangga; (3) Menyiapkan bahan, alat dan media yang diperlukan; (4) Menyiapkan lembar pengamatan ketercapaian masyarakat dalam menerapkan materi penyuluhan dan pelatihan.

\section{Pelaksanaan Tindakan Siklus II}

Pelaksanaan Tindakan Siklus II meliputi (1) Penyuluhan kepada ibu-ibu rumah tangga sekaligus pembentukan kader sadar lingkungan (DARLING); (2) Pelatihan pembuatan pupuk kompos dengan menggunakan decomposer; (3) Pembinaan terhadap kader sadar lingkungan (DARLING); (4) Kader sadar lingkungan (DARLING) bertugas mengedukasi ibu-ibu rumah tangga lainnya mengenai pengelolaan sampah serta mengajak dan mengingatkan ibu-ibu lainnya untuk turut menerapkan sistem $3 \mathrm{R}$ dalam pengelolaan sampah.

\section{Hasil Observasi Siklus II}

Setelah dilaksanakan penyuluhan dan pelatihan pembuatan pupuk kompos sekaligus pembentukan kader sadar lingkungan (DARLING) pada tanggal 8 September 2017, peneliti mengobservasi penerapan sistem ${ }_{3} R$ yang dilakukan oleh warga di lingkungan rumah masing-masing. Hasil yang didapatkan cukup memuaskan. Berdasarkan hasil observasi dan wawancara yang peneliti dapatkan, dengan bantuan kader DARLING, semua responden telah menerapkan salah satu sistem ${ }_{3} \mathrm{R}$ yakni recycle dengan mendaur ulang sampah organic menjadi pupuk kompos.

Refleksi

Berdasarkan hasil observasi siklus II yang didapatkan menunjukkan adanya peningkatan kepedulian terhadap lingkungan yang mencakup pengetahuan, sikap dan penerapan sistem $3 R$. Dengan demikian tindakan dicukupkan pada siklus kedua saja.

\section{Pembahasan}

Berdasarkan data yang didapatkan pada pratindakan, hampir semua responden belum mengetahui tentang pengelolaan sampah yang baik dan benar. Masyarakat banyak yang belum memahami metode pengolahan sampah dengan menggunakan sistem ${ }_{3} \mathrm{R}$ yaitu Reduce, reuse, recycle. Sampah yang dihasilkan setiap harinya, selalu dibuang ke lahan-lahan kosong yang ada disekitar perumahan warga. Ada juga beberapa warga yang dengan sadar membuang sampah ke tempat pembuangan sampah sementara, namun belum memahami metode pengolahan sampah dengan sistem ${ }_{3} R$. Setelah pelaksanaan tindakan pada siklus I, masyarakat mulai mengetahui dan memahami sistem 3 R. Semua responden menjawab pertanyaan dengan benar. Akan tetapi, pada siklus pertama ini hanya terdapat 4 warga saja yang mulai menerapkan pengolahan sampah dengan sistem $3 \mathrm{R}$. Artinya, tindakan pada siklus I belum menunjukkan hasil yang diharapkan. 
JPPM (Jurnal Pendidikan dan Pemberdayaan Masyarakat), 5 (1), 2018 - 7

Henny Helmi, Yanti Karmila Nengsih, Vina Amilia Suganda

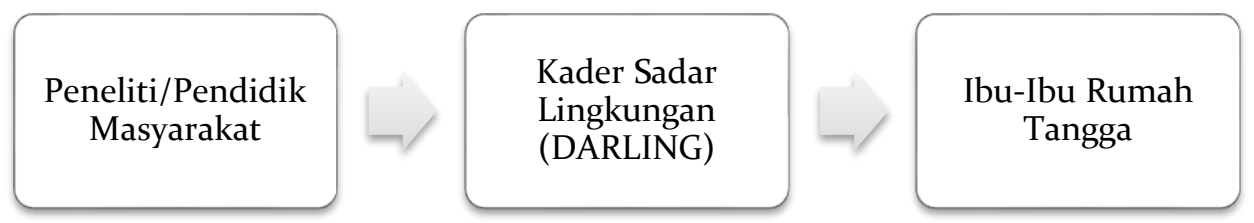

Gambar 1. Model Pembinaan Penerapan Sistem $3 \mathrm{R}$

Pada siklus II materi penyuluhan lebih diperkaya dengan materi tentang etika lingkungan dan juga dikaitkan dengan nilainilai agama. Selain itu pada siklus II, peneliti bersama partisipan membentuk kader sadar lingkungan yang terdiri dari ibu-ibu yang cukup berpengaruh terhadap responden lainnya. Kader sadar lingkungan yang disebut dengan DARLING (sadar lingkungan) di lingkungan RT 30 bertugas membina ibu-ibu lainnya dalam menerapkan sistem ${ }_{3} \mathrm{R}$ di lingkungan rumah masing-masing. Peneliti secara intensif melakukan pembinaan kepada DARLING dalam hal penerapan sistem 3 R. DARLING kemudian membina dan memantau ibu-ibu lainnya dalam hal penerapan sistem $3 R$. Model pembinaan ini dapat dilihat pada Gambar 1.

Mengubah perilaku masyarakat bukanlah perkara yang mudah. Diperlukan usaha yang intensif untuk mencapai hasil yang diinginkan. Dalam meningkatkan kepedulian masyarakat terhadap lingkungan diperlukan upaya pemberdayaan yang berarti mendidik masyarakat dari tidak tahu menjadi tahu, dari tahu menjadi mau, dari mau menjadi mampu untuk melakukan.

Sebagaimana yang dinyatakan Kelsey dan Hearne (1955) bahwa falsafah pemberdayaan adalah "helping people to help them selves", maka dalam proses pemberdayaan diperlukan seorang pekerja sosial yang bertugas sebagai pendidik masyarakat. Pendidik masyarakatlah yang bertugas membantu masyarakat untuk memperoleh pengetahuan, meningkatkan kemampuan sehingga mencapai kehidupan yang lebih baik dari sebelumnya. Pada penelitian tindakan ini, peneliti memposisikan diri sebagai pendidik masyarakat. Peneliti membina kader sadar lingkungan, dan kemudian kader sadar lingkungan membina ibu-ibu rumah tangga lainnya. Hal ini dilakukan dengan pertimbangan bahwa kader lingkungan mempunyai pengaruh yang cukup kuat bagi ibu-ibu lainnya dibandingkan peneliti sendiri. Sehingga hasil yang diharapkan dapat dicapai dengan maksimal.

Model seperti ini bisa dilakukan dari pihak pemerintah kepada masyarakat dalam menerapkan suatu kebijakan tanpa suatu paksaan. Idealnya disetiap keluarahan, ada personal yang menempati posisi sebagai seksi pem-bangunan masyarakat. Seksi pembangunan masyarakat inilah yang bertugas menjadi pendidik masyarakat dan yang membina kader-kader di setiap lingkungan RT. Sayangnya, tidak semua kelurahan yang me-miliki posisi ini. Adapun di kelurahan Kebun Bunga, tercantum bagian Pembangunan Masyarakat, hanya saja tidak ada yang menjabat pada bagian ini, dengan kata lain posisi ini kosong.

Program studi Pendidikan Luar Sekolah merupakan program studi yang berkonsentrasi pada pengembangan sumber daya manusia dan pemberdayaan masyarakat. Salah satu kompetensi yang dimiliki lulusan prodi Pendidikan Luar Sekolah adalah mampu memberdayakan masyarakat melalui program-program pendidikan yang dirancang sesuai dengan kebutuhan masyarakat. Dengan demikian, sangatlah tepat jika lulusan prodi Pendidikan Luar Sekolah menempati posisi sebagai seksi pembangunan masyarakat di setiap kelurahan. Lulusan prodi Pendidikan Luar Sekolah sudah tersebar di berbagai daerah. Oleh karena itu, posisi seksi pembangunan masyarakat semestinya ada dan terisi dalam setiap kelurahan. Hal ini perlu direalisasikan agar pembangunan manusia Indonesia seutuhnya dapat terwujud dan terlaksana. 
JPPM (Jurnal Pendidikan dan Pemberdayaan Masyarakat), 5 (1), 2018 - 8

Henny Helmi, Yanti Karmila Nengsih, Vina Amilia Suganda

\section{SIMPULAN}

Berdasarkan hasil penelitian ini, dapat disimpulkan bahwa; (1) Ada peningkatan kepedulian terhadap lingkungan yang mencakup pengetahuan, sikap dan perilaku melalui pembinaan penerapan sistem 3 R. (2) Proses pembinaan dari fasilitator/pendidik masyarakat terhadap kader DARLING dan dari kader DARLING terhadap masyarakat lainnya harus dilaksanakan secara intensif. (3). Kasi Pembangunan Masyarakat di setiap kantor Kelurahan hendaknya terisi dan bertugas sebagai fasilitator/pendidik masyarakat.

\section{DAFTAR PUSTAKA}

Burns, Anne. (1999). Collaborative Action Research for English Languange Teachers. London: Cambridge University Press.

Darsono, V. (1995). Pengantar ilmu lingkungan. Yogyakarta: Universitas Atma Jaya Yogyakarta.

Irwan, Z. D. (2007). Prinsip-prinsip ekologi:
Ekosistem, lingkungan dan pelestariannya. Jakarta: PT Bumi Aksara.

Kesley, L.D \& C.C. Hearne. (1955). Cooperative Extension Work. Ithaca: Comstock Publishing Associates

Madya, Suwarsih. (2007). Teori dan Praktik Penelitian Tindakan. Bandung: Alfabeta

Neolaka, A. (2008). Kesadaran lingkungan. Jakarta: Rineka Cipta.

Presiden Republik Indonesia. UndangUndang Republik Indonesia Nomor 32 Tahun 2009 tentang perlindungan dan pengelolaan lingkungan hidup, Pub. L. No. 32, Undang-Undang Republik Indonesia (2009).

Soemarwoto, O. (1997). Ekologi, lingkungan hidup, dan pembangunan. Bandung: Djambatan.

Sugiyono. (2015). Metode Penelitian Tindakan Komprehensif. Bandung: Alfabeta 